Volume 5, Issue 3, October 2020, pp. 289-303

DOI: $10.23917 /$ jramathedu.v5i3.10061

p-ISSN: 2503-3697, e-ISSN: 2541-2590

\title{
Challenging primary school students' attitude toward calculators
}

\author{
Russasmita Sri Padmi \\ SEAMEO QITEP in Mathematics, Indonesia \\ Corresponding author: r.sripadmi@staff.qitepinmath.org
}

\begin{tabular}{l} 
ARTICLE INFO \\
\hline Article history: \\
Received: 30 January 2020 \\
Revised: 24 June 2020 \\
Accepted: 30 June 2020 \\
Published online: 14 August \\
2020 \\
Published regularly: October \\
2020
\end{tabular}

ABSTRACT

Calculators are a viable option for educational technology in developing countries due to its affordability and accessibility; it is also supported by literature to have positive effects on the students' acquisition of mathematics concepts and skills positively. However, the stakeholders of education in Indonesia often stigmatize the use of calculators in mathematics classrooms, especially in primary school. This is in contrast with the policy of many developing countries which include calculator as one of the educational technologies to be used in the classroom. This study aims to investigate the effect of calculator-enhanced mathematics lessons on the attitude of primary school students'. Fourth-grade students $(\mathrm{n}=95)$ in four separate schools with minimum calculator experience participated in this study. The questionnaire was administered before and after the lesson to record their attitude. The use

Keywords:

calculator, attitude, technology of a well-established scale ensured validity, while the Cronbach-Alpha score confirmed reliability. Data analysis was conducted through the comparison of mean value between pre- and post-questionnaires scores. The finding suggests that while the effect on attitude toward mathematics is somewhat mixed, there is a significant improvement in the students' attitude toward using calculators to learn mathematics. Calculatorenhanced mathematics lessons help the students foster more positive attitudes toward calculators. The finding of the present study is expected to help teachers to challenge the stigma about calculator and thus can benefit from calculator to enhance their lesson.

(C)2020 Universitas Muhammadiyah Surakarta

\section{Introduction}

In modern education, ICT (information and communication technology) offers endless possibilities to make mathematics learning more innovative and engaging. Research has scientifically demonstrated that the integration of ICT in mathematics learning has a positive impact on both cognitive and affective domain (Chauhan, 2016; Cheung \& Slavin, 2013; Savelsbergh et al., 2016). Various educational institutions and professional associations across the world advocate ICT as an integral part of modern education. For example, the National Council of Teachers of Mathematics (2014) espouses Tools and Technology as one of the guiding principles to school mathematics. According to this principle, an excellent mathematics curriculum includes mathematical tools and technology as essential resources to support students in understanding mathematical

To cite this article:

Sri Padmi, R. (2020). Challenging primary school students' attitude toward calculators. JRAMathEdu Journal of Research and Advances in Mathematics Education), 5(3), $289-303$. doi:https://doi.org/10.23917/jramathedu.v5i3.10061 
ideas, conducting mathematical reasoning, and communicating their thinking to a wider audience (NCTM, 2014, p.5).

Educational technology encompasses programs or applications which are integrated into classroom activities to support the attainment of learning goals (Cheung \& Slavin, $\underline{2013}$ ). This notion of educational technology can take many forms, such as computer-based instruction, games, or interactive quizzes.

Regarding the integration of ICT in education, computer and the internet might be an obvious choice due to a wide array of games, applications, and interactivity they support. However, in developing countries, computers and the internet are not always readily available for all student demographics. In Indonesia, on average, there is only one computer available for every 16,7 students, and only $25.8 \%$ of students have at least one computer at home (OECD, 2015). There is immense inequality within the country as well, with some regions in Indonesia have much more difficult access to educational technology than others.

The gap between the number of students and the availability of computers calls for an alternative form of technology. An example of educational technology that can be considered is scientific calculators. Scientific calculators are hand-held computing tools whose use in the classroom started to reach global popularity in the 1970-s (Boorman, 2015). For the sake of convenience, this article will refer to scientific calculators as calculators.

The calculator can be a viable option to integrate educational technology in developing countries (Kissane \& Kemp, 2014). Compared to other forms of technology, calculators tend to be more affordable and accessible. They are also portable and conveniently sized, which means easier to set up, store, and transport. Using calculators also eliminate the need for supporting technology, such as electricity and the internet.

Nevertheless, ever since its widespread introduction, the use of calculator in mathematics teaching and learning has ignited a never-ending polemic. Most parents, teachers, and policymakers believe that sustained use of calculators in grades $\mathrm{K}-12$ will have detrimental effects on the students' acquisition and retention of fundamental mathematics skills, especially in lower educational stages (Banks, 2011; da Ponte \& Mercê, 2011; Richardson, 2014). The discussion on the use of ICT to improve mathematics learning often leaves out calculators (Savelsbergh et al., 2016). Even in countries where educational use of calculators is advocated by the government and explicitly suggested in the curriculum, the progress to accept calculator into the school environment takes a long time due to parents' and teachers' hesitance (Banks, 2011; da Ponte \& Mercê, 2011). Some countries opt for a total ban of calculators from schools. In Indonesia, using calculators is perceived as cheating, as evident in the policy of prohibiting calculators in national examination (BNSP, 2020).

Research in this field, however, reports contradicting evidence. The use of calculator in mathematics learning is discovered to impact the students' learning positively. Studies have shown that the use of calculator alongside traditional instruction improves the students' attainment of basic mathematics and problem-solving skills (Ronay et al., 2011). Such findings are consistent across grades, even in primary school. Calculators relieve the students from the burden of procedural calculations, allowing them to focus on meaningful problem-solving in purposeful contexts (Richardson, 2014).

Calculators also have positive effects upon the affective domain. The use of calculator increases the students' interest and motivation in mathematics (Tan, Harji, \& Lau, 2011), as well as support the students in maintaining affective pathway during the problem-solving process (McCulloch, 2011). Using calculators in the classroom also fosters a more positive 
outlook on mathematics problem solving (Parrot \& Leong, 2018). The students can work with real and messy numbers without being burdened by routine calculation procedures.

National Council of Teachers of Mathematics (NCTM, 2015) fully endorses calculators as part of educational technology. They state that the use of calculators is supposed to support mental and manual calculations, not replace them. Therefore, the issue is not about whether calculators should be used in mathematics learning, but how to use it.

To summarize, the explanation above gives rise to three points of consideration, namely the benefit of ICT, the suitability of calculator as starting educational ICT in developing countries, and the positive research finding regarding the educational use of calculators. Therefore, it can be deduced that the stigma against using calculators for educational purpose is no longer relevant, and the use of calculator in mathematics classrooms in Indonesia is an idea worth pursuing.

However, since the stigma against calculators has lasted for generations, an attempt to introduce them in school instruction will possibly be met with apprehension. The students will likely to resist or avoid calculator in the classroom because they think it is merely a tool for easier calculating or worse, cheating. Their potential reaction needs to be carefully addressed because their attitude can interfere even when a pedagogical approach is successful. For example, the study by McCulloch (2011) described that the students still feel guilty about using calculators, even when it obviously supports their affective pathway. On the contrary, the students who are accepting of calculator tend to be more adept and less anxious in problem-solving, because they can focus on the process and leave the burden of computation to calculators, as reported in separate studies by Korr and Schrup (Tan et al., 2011).

Therefore, the urgency lies in finding out what kind of calculator-enhanced mathematics lesson will not be met with apprehension by the students and instead promote a positive attitude toward mathematics and calculator in mathematics.

So far, there is minimal research on innovative calculator-enhanced mathematics lesson in primary school, especially in Indonesia. This study aims to design a learning experience to promote a healthy attitude toward the use of calculator in mathematics learning. We differentiate between the attitude toward calculator and mathematics because it is possible that the students like learning with calculators, but hate mathematics, or the other way around. To accomplish the aim of this study, the researchers strived to answer the overarching research question of how the use of calculator affect primary school students' attitude in mathematics classroom, which is further divided into two subquestion. The first question is: "What is the impact of the use of calculator toward $4^{\text {th }}$-grade students' attitude toward using calculators to learn mathematics?", while the second question is: "What is the impact of the use of calculator toward 4th-grade students' attitude toward mathematics?". The finding of this study is to encourage teachers to challenge the stigma of using calculators in mathematics classrooms, especially in primary schools.

\section{Research Method}

This study is conducted through design research aimed to design learning materials incorporating calculators for primary school mathematics.

\section{Designing Classroom Activities}

Kissane (2017) summarized four strategies for the use of calculators in the classroom: calculation, affirmation, exploration, and representation. The calculation function indicates using calculators to perform computation otherwise impossible to perform by hand, while affirmation implies its use to confirm the result of prediction or 
estimation. Exploration means using it as a tool to explore different concepts and ideas, while representation implies using calculators to depict numerical representation.

As highlighted in the previous section, the leading cause of apprehension toward calculators is due to the calculator's reputation as a mere computing aid. Therefore, during the design phase, this study strived to incorporate calculators into the classroom activities with minimum computing function. Instead, we maximized other roles as specified by Kissane above. Figure 1 shows the translated version of the example of the problems.

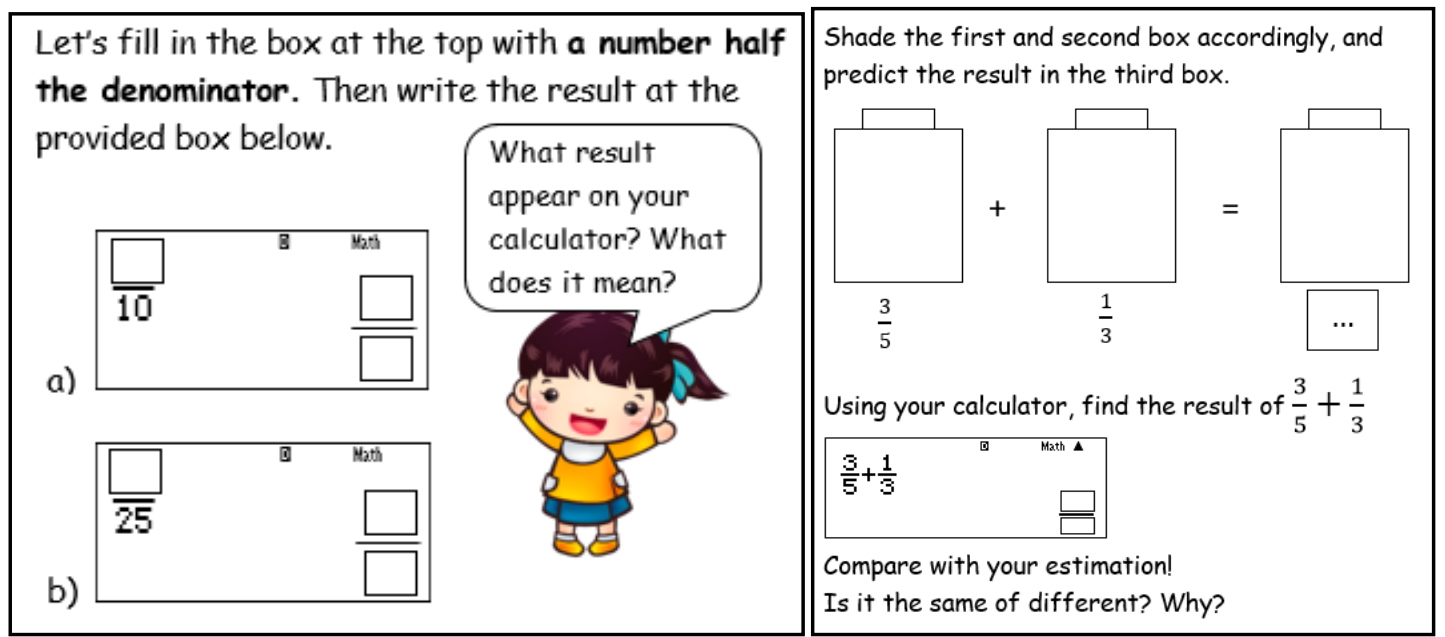

Figure 1.Example of problems incorporating calculators (translated to English)

The topic chosen for this study is fraction addition with estimation. The first problem is an example of exploration. By trying out several options for the numerator, the students are expected to see the pattern and able to make a conclusion about the equivalent fractions. They are given a chance to experiment not only with even numbers but also with odd ones, in order to provide more challenges in determining the half.

The second problem is an example of affirmation, where the students can estimate the result of fraction addition before using calculators to check their estimation. The conjecture is that the students will get different answers for their estimation and calculation. We expect the students to reason about the difference between estimation and calculation with their knowledge on the equivalent fractions. It is evident that both problems do not simply use calculators as a tool to calculate numerical answers.

The worksheet itself consists of two parts; the first part (prerequisite knowledge) contains the first problem, while the second one (the main worksheet) consists of the second problem. The designed learning materials, consisting of worksheet and lesson plan were first validated through expert validation and pilot experiment.

As the schools do not permit the use of calculators, limited experience with calculators as an educational tool does not only apply for the students but also the teachers. Therefore, we conducted a 4-day workshop for the participating teachers for them to learn about the technical and educational aspects of calculators. This workshop ensured that the teachers acquired enough competency and confidence to deliver a calculator-enhanced lesson.

An open-ended questionnaire was given before and after the workshop to monitor the change in the teachers' perception. From 30-workshop participants, 13 participants have used calculators in their classroom before the workshop. Out of those, only one teacher described using calculators to explore mathematics concept, while almost all the 
rest of the teachers claimed only uses calculators as a calculating device. While the majority (23) teachers agreed that calculators are suitable for use in primary school, their reasons are mainly about using calculators to assist with calculation. After the workshop, all teachers agreed that calculators are suitable to be used in primary school. They stated that since calculators do not only function as computing tool but also can support teachers in making rich and meaningful activity, it is no longer detrimental for the students' understanding.

\section{Data collection and analysis}

In measuring the students' attitude toward using technology to learn mathematics, the present study uses Mathematics and Technology Attitude Scale (MTAS) (Pierce, Stacey, \& Barkatsas, 2007). MTAS encompasses both the attitude toward mathematics and the attitude toward using technology to learn mathematics. This instrument consists of five subscales, namely mathematics confidence (MC), affective engagement (AE), behavioral engagement (BE), confidence with technology (TC), and attitude toward learning mathematics with technology (MT). Each subscale comprises four statements with 5-point Likert scale responses, resulting in 20 statements in total with a minimum score of four and a maximum of 20 for each subscale. The scale considers scores of 17 or above to be high, signifying a very positive attitude; 13-16 as moderate; and 12 or below as low, indicating negative attitude.

In accordance with the research questions, we used MTAS to collect the data on the students' attitudes. However, because MTAS was designed for middle secondary school students, some adjustments are necessary to make the statements more suited to primary school students. First, the items on confidence with technology (TC) subscale were omitted, on the ground that $4^{\text {th }}$ grade students are unlikely to possess sufficient experience with technology to give meaningful responses for this section. Second, the scales for each statement is accompanied with smileys to ease the students in designating proper response (Elyazgi, 2018). The statements were translated into simpler sentences in the Indonesian language without changing the meaning and validated through peer evaluation. The final questionnaire consists of 16 questions and four subscales (Appendix).

Validity is ensured through the use of a well-established scale. As the subscales of MTAS are independent of each other, excluding TC subscales does not affect the content validity. Reliability analysis resulted in reasonable Cronbach's Alpha values for the first three subscales (BE, .62; MC, .63; AE, .56), and satisfactory result of .88 for MT. The score indicates acceptable internal consistency within each subscale.

The first research question on the students' attitudes toward mathematics is answered by comparing the difference in average student scores for $\mathrm{BE}, \mathrm{MC}$, and $\mathrm{AE}$ subscales between pre- and post-questionnaire. On the other hand, the second research question on the students' attitude toward using calculators to learn mathematics is answered through comparing the average student scores for the MT subscale. We ensured normal distribution through the Shapiro-Wilk test and administered the subsequent mean comparison for pre- and post-questionnaire scores through one-tailed paired sample t-test with a significance level of 0.05 .

\section{Research setting}

The participants of this study are $954^{\text {th }}$ grade students from four different classes. Each class comes from different primary schools of the same curriculum and similar academic level in Yogyakarta, with varying sizes from 20 to 29 students. Each class comprises students of heterogeneous academic ability and average socio-economic 
background. While the students are familiar with calculators, the schools do not allow calculators and they are mostly apprehensive toward using it to learn mathematics in school. The regular teacher, who has participated in the preparatory workshop, taught the lesson. We administered the MTAS before and after the lesson.

The lesson consists of one meeting lasting for 70 minutes. During the lesson, each student was equipped with scientific calculators and encouraged with written instruction to use it throughout the lesson.

\section{Results and Discussion}

A brief explanation of the lesson is as follows. The lesson was set in the context of biogas, whose purpose is to make the lesson more relevant and grow the students' awareness of environmental issues. The lesson was started by recalling prerequisite knowledge (adding and subtracting simple fractions such as $1 / 2$ and 1), followed by the teacher introducing the context of biogas and the problem. In this lesson, the students' task is to add the content of barrels. However, since they have not learned about operations with fractions before, and the problems only contain non-simple fraction (such as 1/3 and $3 / 5$ ), the students will have to use approximation. The calculator, in this case, will help the students solve the problem.

Example of the students' answer to the first problem is as depicted in Figure 2. Generally, the students did not have any difficulty finding the number that is half of the denominator as long as the half is a whole number. Yet, they started to have problems when the half is not whole. The teacher addressed the students' difficulty when the class discussed the problem together, followed by having the students finding the half of various numbers and put it into the calculator. In the end, they were able to understand the idea of equivalent fractions, especially the equivalence of $1 / 2$ and 1 .

a)

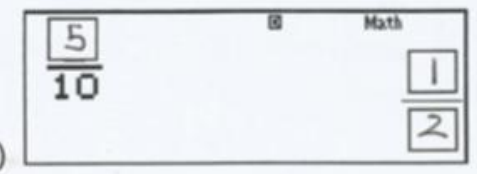

b)

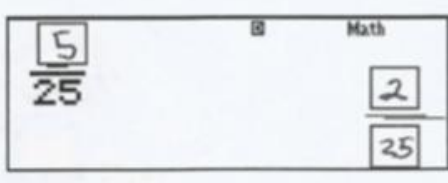

Apa he

muncu

kalkuls

a)

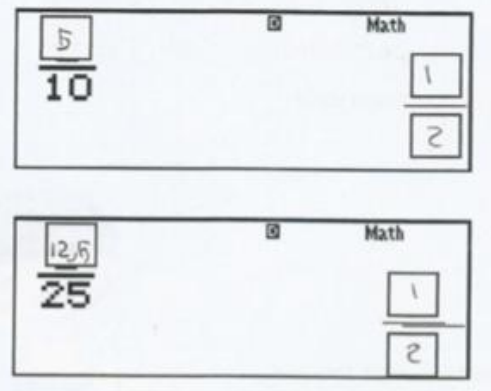

Apa hi

muncu

kalkul

Figure 2. Some example of the students' answer to the first problem

As for the second problem, one example of the students' answer is depicted in Figure 3. In the first part, the student divided the drawing horizontally into five parts, then shaded the number of parts according to the nominator. Some students did it differently, like dividing them vertically or shading the top parts of the barrel, which was addressed by the teacher by asking the students to reflect the context, "If you fill a barrel with cow dung, does it make sense if the barrel fills up this [pointing to the students work] this way?"

They started to take difficulty when adding the content of the first and second problem. They have not learnt about the addition of fractions with different denominator before, so they cannot add the fraction through arithmetic operations. However, looking at the content of the barrel, most students guessed the third barrel is supposed to be full or almost full. In this worksheet, they finally wrote " 1 ", after some struggle; writing, erasing, 
and writing again. In the second part, calculating with calculator yielded the result “ $\frac{14}{15}$ ” which is close to " 1 " or full barrel, as the student discovered afterwards.

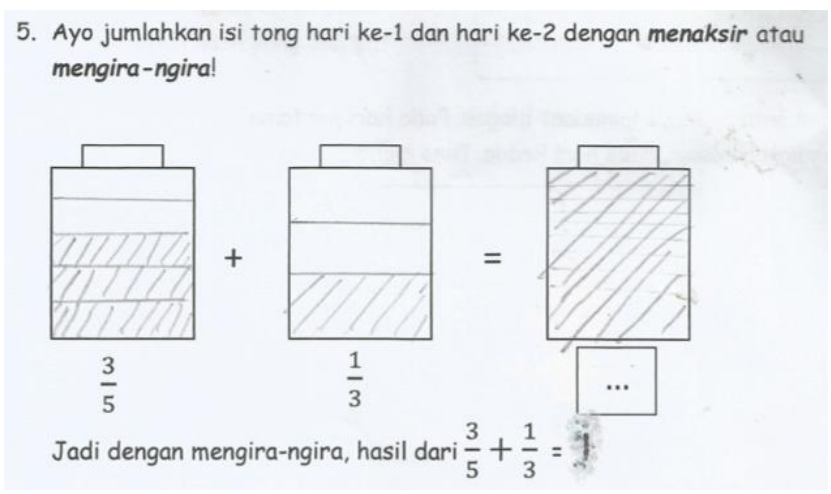

Translation:

Let's add up the content of the barrel in day 1 and day 2 by approximating

So, by approximating, what is the result of the following calculation?

$$
\frac{3}{5}+\frac{1}{3}=\ldots
$$

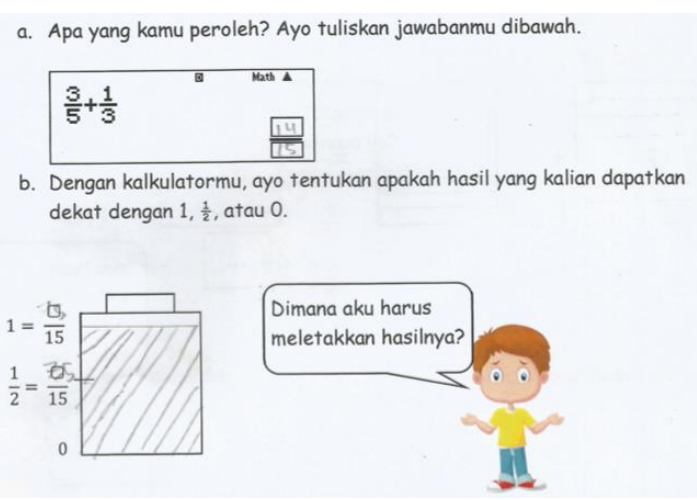

Translation:

What do you get? Write your answer below.

With your calculator, determine whether the result is close to $1,1 / 2$, or 0 .

(Inside the speech bubble) where should I put the result?

Figure 3. An example of the students' answer to the second problem.

Another example of the students' answer is provided in Figure 4. After dividing by parts in question 1 and 2 , the student decided to just approximate $\frac{3}{5}$ and $\frac{1}{3}$ with $1 / 2$ in question 5 . While they started to understand that " $1 / 2$ " combined with " $1 / 2$ " might equal " 1 ", they have not learnt about fraction addition with different denominators and got confused with the calculation. They decided to add the numerator with numerator and denominator with denominator, resulting in “ $\frac{4}{8}$ ”. The teacher addressed this by asking the student to reflect on the context. "If half a barrel is combined with half a barrel, what would you get?".

1. Arsirlah tong di bawah ini didapat Dino di hari perta

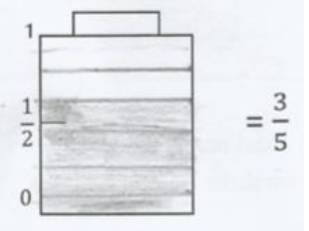

2. Arsirlah tong di bawah ini didapat Dino di hari keduc

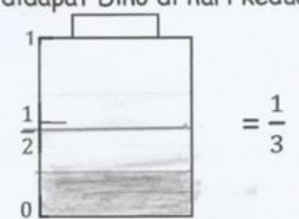

5. Ayo jumlahkan isi tong hari ke-1 dan hari ke-2 dengan menaksir atau mengira-ngira!
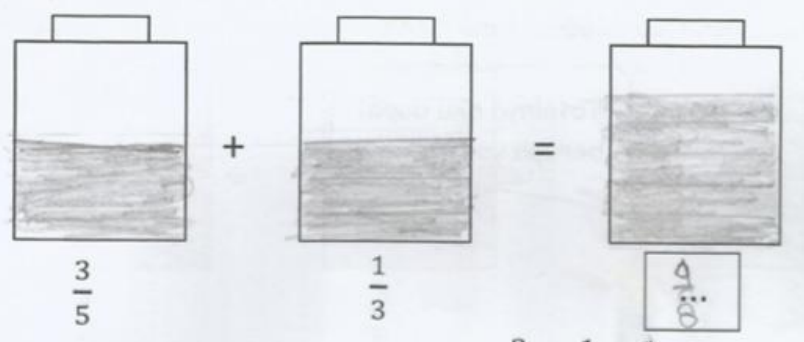

Jadi dengan mengira-ngira, hasil dari $\frac{3}{5}+\frac{1}{3}=\frac{4}{8}$

Translation:

1. Shade the following barrel based on what Dino get in the first day. 2. Shadethe following barrel according to what Dino get in the second day.

5. Let's add up the content of the barrel in day 1 and day 2 by approximating.So, by approximating, what is the result of the following calculation? $\frac{3}{5}+\frac{1}{3}=\ldots$ 
a. Apa yang kamu peroleh? Ayo tuliskan jawabanmu dibawah.

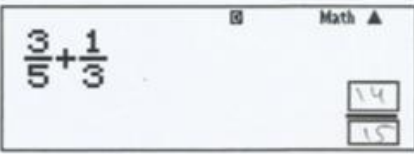

b. Dengan kalkulatormu, ayo tentukan apakah hasil yang kalian dapatkan dekat dengan $1, \frac{1}{2}$, atau 0 .
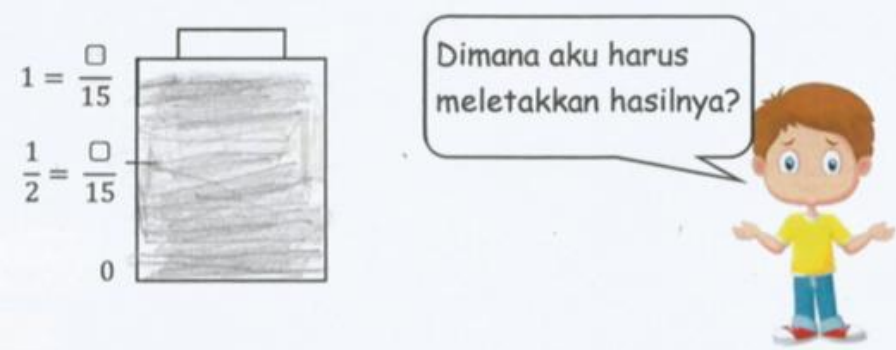

Translation:

a. What do you get (by using calculator)? Write the answer on the box below.

b. With your calculator, determine whether the result you get is close to $1,1 / 2$, or 0 .

(Inside the speech bubble) where should I put the result?

Figure 4. An example of the students' answer to the second problem.

In the following explanation, we report the result of data analysis in response to the first and second research questions. The result from school 1 to 4 is depicted in Table 1 to 4 , respectively.

Table 1

Pre- and post-questionnaire scores in school $1(n=20)$

\begin{tabular}{|c|c|c|c|c|}
\hline Subscale/Test & $\bar{x}$ & SD & $\mathrm{t}$ & $\mathrm{p}$ \\
\hline \multicolumn{5}{|c|}{ Behavioral engagement (BE) } \\
\hline Pre- & 13.45 & 3.18 & \multirow{2}{*}{1.083} & \multirow{2}{*}{.146} \\
\hline Post- & 14.25 & 3.89 & & \\
\hline \multicolumn{5}{|c|}{ Confidence with mathematics (MC) } \\
\hline Pre- & 15.05 & 3.23 & \multirow{2}{*}{-.958} & \multirow{2}{*}{.175} \\
\hline Post- & 14.05 & 3.92 & & \\
\hline \multicolumn{5}{|c|}{ Affective engagement (AE) } \\
\hline Pre- & 14.6 & 3.53 & \multirow{2}{*}{-.711} & \multirow{2}{*}{.243} \\
\hline Post- & 13.9 & 3.89 & & \\
\hline \multicolumn{5}{|c|}{ Attitude toward learning mathematics with technology (MT) } \\
\hline Pre- & 6.65 & 2.92 & \multirow{2}{*}{4.162} & \multirow{2}{*}{.0005} \\
\hline Post- & 9.9 & 4.15 & & \\
\hline
\end{tabular}

In school 1, it was evident from the pre-questionnaire score that the students entered the lesson with a moderate attitude toward mathematics but exceptionally low score on MT scale, indicating negative perspective on using calculators in mathematics classrooms. The result of mean comparison between pre- and post-questionnaire show that the impact of the calculator-enhanced lesson is inconsistent across attitude toward mathematics subscales. The score for BE increases while the opposite happens for AE and CT, although it is worth noting that the difference is not statistically significant. 
Table 2

\begin{tabular}{|c|c|c|c|c|}
\hline \multicolumn{5}{|c|}{ Pre- and post-questionnaire scores in school $2(\mathrm{n}=20)$} \\
\hline Subscale/Test & $\bar{x}$ & SD & $\mathrm{t}$ & $\mathrm{p}$ \\
\hline \multicolumn{5}{|c|}{ Behavioral engagement (BE) } \\
\hline Pre- & 13.7 & 2.49 & \multirow{2}{*}{2.84} & \multirow{2}{*}{.005} \\
\hline Post- & 15.45 & 2.14 & & \\
\hline \multicolumn{5}{|c|}{ Confidence with mathematics (MC) } \\
\hline Pre- & 14.3 & 2.47 & \multirow{2}{*}{3.715} & \multirow{2}{*}{.0005} \\
\hline Post- & 16.1 & 2.19 & & \\
\hline \multicolumn{5}{|c|}{ Affective engagement (AE) } \\
\hline Pre- & 16.1 & 2.88 & \multirow{2}{*}{.644} & \multirow{2}{*}{.264} \\
\hline $\begin{array}{l}\text { Post- } \\
\text { Attitude towarc }\end{array}$ & 16.5 & 3.2 & & \\
\hline \multicolumn{5}{|c|}{ Attitude toward learning mathematics with technology (MT) } \\
\hline $\begin{array}{l}\text { Pre- } \\
\text { Post- }\end{array}$ & $\begin{array}{l}10.35 \\
16.55\end{array}$ & $\begin{array}{l}3.99 \\
3.25 \\
\end{array}$ & 6.851 & $<.0001$ \\
\hline
\end{tabular}

Similar to the previous cycle and school, the students in school 2 started the lesson with moderate scores in all subscale except MT, which is much lower than the other scales even though it is still higher than the previous school. The result shows there is an increase in $\mathrm{BE}, \mathrm{MC}$, and $\mathrm{AE}$ subscales, indicating an improvement in the students' attitude toward mathematics. The differences are all statistically significant, except for AE.

Table 3

Pre- and post-questionnaire scores in school $3(\mathrm{n}=27)$

\begin{tabular}{lllll}
\hline Subscale/Test & $\bar{x}$ & SD & $\mathrm{t}$ & $\mathrm{p}$ \\
\hline Behavioral engagement (BE) & & & \\
$\quad$ Pre- & 14.37 & 3.11 & .144 & .307 \\
$\quad$ Post- & 14.44 & 3.39 & & \\
Confidence with mathematics (MC) & 14.18 & 2.96 & & \\
$\quad$ Pre- & 14.41 & 2.97 & .587 & .195 \\
$\quad$ Post- & & & \\
Affective engagement (AE) & & & \\
$\quad$ Pre- & 14.77 & 3.47 & -.091 & .32 \\
$\quad$ Post- & 14.74 & 3 & & \\
Attitude toward learning mathematics with technology (MT) & & \\
Pre- & 13.03 & 3.65 & 1.562 & .004 \\
Post- & 14 & 3.7 & & \\
\hline
\end{tabular}

Table 4

Pre- and post-questionnaire scores in school $4(n=24)$

\begin{tabular}{lllll}
\hline Subscale/Test & $\bar{x}$ & SD & $\mathrm{t}$ & $\mathrm{p}$ \\
\hline Behavioral engagement (BE) & & & & \\
$\quad$ Pre- & 15.3 & 3.25 & 2.03 & .027 \\
$\quad$ Post- & 16.3 & 2.8 & & \\
Confidence with mathematics (MC) & 13.54 & 2.76 & & \\
$\quad$ Pre- & 14.6 & 2.58 & 3.513 & .001 \\
$\quad$ Post- & & & \\
Affective engagement (AE) & 15.96 & 2.47 & & \\
$\quad$ Pre- & 16.66 & 2.51 & 1.726 & .049 \\
$\quad$ Post- & 6.83 & & \\
Attitude toward learning mathematics with technology (MT) & & \\
$\quad$ Pre- & 14.9 & & \\
$\quad$ Post- & 4.76 & 7.528 & $<.0001$ \\
\hline
\end{tabular}

The students in school 3 started with moderate scores in all subscales, including MT. Scores between pre- and post-questionnaire do not differ much. Out of three subscales 
related to attitude toward mathematics, only $\mathrm{BE}$ and $\mathrm{MC}$ exhibited a slight increase in their scores. In contrast, the score for $\mathrm{AE}$ drops, although by several decimal points. Furthermore, the differences are not statistically significant.

In the last school, the students started with a moderate attitude toward mathematics and a very low score in the MT subscale. Between pre- and post-questionnaire, statistically significant increases are visible in $\mathrm{BE}, \mathrm{MC}$, and $\mathrm{AE}$ subscales, showing an improvement in students' attitudes toward mathematics.

As for attitude toward using calculators to learn mathematics, it was evident that the students in all schools started with low scores in MT subscales, signifying a strong aversion toward using calculator to learn mathematics. After the lesson, MT scores in postquestionnaire in all schools experienced a statistically significant increase from the prequestionnaire scores, indicating an improvement in the students' attitude toward the use of calculator in the mathematics classroom. From the result of analysis on the attitude data, two findings are apparent. First, the impact of calculators on the students' attitude toward mathematics is either inconsistent or statistically insignificant. Second, there is a statistically significant improvement in the students' attitude toward using calculators to learn mathematics.

The first finding is inconsistent with literature. This can be explained by the short duration of the lesson, considering most significant studies reporting favorable effects of calculators on the students' attitude toward mathematics are conducted over a much longer period of time (Kandemir \& Demirbağ-Keskin, 2019; Parrot \& Leong, 2018; Ronay et al., 2011).

Pre-questionnaire scores for the MT (learning mathematics with technology) subscale are the lowest compared to the other subscales, and this trend is consistent across schools. This finding is in line with those from Pierce et al., (2007) and Mendezabal and Tindowen (2018), that also noted low scores in MT subscale indicating prevalent aversion among students toward calculator use in the classroom. Furthermore, this aversion can persist well into adulthood and may relate to adult proficiency with calculator, as shown in a study on teachers' perception regarding calculators by Taley and Adusei $(\underline{2020})$. The study noted that positive perception toward strongly influences with teachers' level of competency.

The second finding is consistent with the findings reported in Mendezabal and Tindowen (2018), in which the pre-test score for MT subscale is the lowest, and it increases significantly higher than the other subscales during post-test. The study by Retnawatiet et. al. (2019) also found that integration of calculator enhances the students' participation in mathematics learning. The finding signifies that the implementation of the calculatorenhanced learning activities helps improve the students' attitude regarding the use of calculator in learning mathematics. This proves that with the right activity, calculatorenhanced lessons do not have to cause negative perception in students. Instead, it can foster a positive attitude and engagement toward the lesson.

Findings from the literature on the students' attitudes toward computers suggest a positive relationship between experience and attitude; the more experience the students have with a computer, the better the perspective they possess toward it (Dündar \& Akçayir, 2014). One might predict that a similar relationship can occur with calculators. The findings of this study confirm this prediction; attitude toward the use of calculator in the classroom saw statistically significant improvement after the students' participated in the calculator-enhanced lesson. Experience with calculators might be contributed as the reason behind this improvement.

Another factor worth considering is the novelty. Studies have noted that novelty, such as new teaching strategies or resources, has a significant role in students' attitudes toward 
mathematics (Savelsbergh et al., 2016). In fact, the study by Pierce et al. (2007) also found that the students with the most positive attitude toward calculator come from school recently having experience in it.

Evidently, this might make one doubt whether the students' positive attitude toward calculator is a lasting phenomenon caused by the approach on how the calculator is used to support their learning, or simply a short-lived excitement caused by trying something new. However, the approach to incorporating calculators in this study (Ruthven, 2003) have been found to cause a lasting positive impression on the students in longitudinal research. Therefore, we might contribute the favorable findings regarding the students' attitude toward calculators to the way calculators are being integrated into classroom activities.

\section{Conclusion}

Calculator-enhanced mathematics lesson with a focus on the exploration and representation function of calculators is potentially an effective way to foster the students' positive attitude toward calculator. The students experienced that the use of calculators in mathematics classrooms does not necessarily imply a lack of thinking process or even cheating. By focusing on the exploration and representation function, calculators can offer exciting and engaging activities in mathematics classrooms. As calculator has been continually proven by research to be a great support tool for mathematics learning, helping the students possess a more positive attitude toward calculator can be a start before further integration in mathematics lessons.

The finding of this study is expected to be a pointer for teachers interested in challenging the paradigm on the use of calculator in mathematics classrooms, especially in primary schools. Instead of avoiding calculators altogether, teachers should take the challenge of integrating technology without causing dependency as a chance to create more innovative lessons. Another contribution anticipated from the finding of this study is a less stigmatized view of calculators. It may encourage teachers with inadequate access to computer and internet to explore calculator instead, in an attempt to ensure equal access to educational technology for all students in Indonesia. Furthermore, the finding of this study is expected to contribute to policymaking and advocating regarding the place of calculators in the Indonesian mathematics curriculum.

Finally, the limitations of this study include time and curricular constraints, which limit the duration of the teaching experiment to one meeting only. While the discussion in the previous section already shows how the result of this short-term study stands well against other longitudinal studies, further studies are suggested to venture on a longer duration of the lesson for more consistent observation regarding attitude toward mathematics. We also recommend future research to focus on how the attitude toward mathematics might influence attitude toward using calculators to learn mathematics or vice versa.

\section{Acknowledgment}

This work is supported by the yearly program fund of SEAMEOQITEP in Mathematics. The author thanks the teachers and students in SD Gendengan, SDN Sorogenen, SDN 5 Sleman, and SDN Kedungpring who have participated in this study, and the colleagues in Research and Development division of SEAMEOQITEP in Mathematics.

\section{Bibliography}

Banks, S. (2011). A Historical Analysis of Attitudes Toward the Use of Calculators in Junior 
High and High School Math Classrooms in the United States Since 1975 (Master's Thesis, Cedarville University). https://doi.org/10.15385/tmed.2011.1

BNSP. (2020). Prosedur Operasional Standar Penyelenggaraan Ujian Nasional Tahun Pelajaran 2019/2020. Retrieved from https://bsnp-indonesia.org/standar-penilaianpendidikan/

Boorman, D. (2015). Should Primary School Children be "Calculator Aware" or "Calculator Beware." Teacher Education Advancement Network Journal, 7, 74-85.

Chauhan, S. (2016). A meta-analysis of the impact of technology on learning effectiveness of elementary students. Computers and Education. https://doi.org/10.1016/i.compedu.2016.11.005

Cheung, A. C. K., \& Slavin, R. E. (2013). The effectiveness of educational technology applications for enhancing mathematics achievement in K-12 classrooms: A metaanalysis. Educational Research Review, 9, 88-113. https://doi.org/10.1016/i.edurev.2013.01.001

da Ponte, J. P., \& Mercê, C. (2011). A teacher education experiment to challenge conceptions and practices. ZDM - International Journal on Mathematics Education, 43(6), 847-859. https://doi.org/10.1007/s11858-011-0349-y

Dündar, H., \& Akçayir, M. (2014). Implementing tablet PCs in schools: Students' attitudes and opinions. Computers in Human Behavior, 32, 40-46. https://doi.org/10.1016/j.chb.2013.11.020

Elyazgi, M. (2018). Review of Gathering Data Instruments and Methods in Children Research. International Journal of Engineering \& Technology, 7(3.21), 311. https://doi.org/10.14419/ijet.v7i3.21.17179

Kandemir, M. A., \& Demirbağ-Keskin, P. (2019). Effect of graphing calculator program supported problem solving instruction on mathematical achievement and attitude. International Journal of Research in Education and Science, 5(1), 203-223.

Kissane, B. (2017). Learning with Calculators: Doing More with Less. Australian Mathematics Teacher, 73(1), 3-11. Retrieved from http://www.aamt.edu.au/Webshop/Entire-catalogue/Australian-MathematicsTeacher

Kissane, B., \& Kemp, M. (2014). A model for the educational role of calculators. In Proceedings of the 19th Asian Technology Conference in Mathematics.

McCulloch, A. W. (2011). Affect and graphing calculator use. Journal of Mathematical Behavior, 30(2), 166-179. https://doi.org/10.1016/j.jmathb.2011.02.002

Mendezabal, M. J. N., \& Tindowen, D. J. C. (2018). Improving students' attitude, conceptual understanding and procedural skills in differential Calculus through microsoft mathematics. Journal of Technology and Science Education, 8(4), 385-397. https://doi.org/10.3926/jotse.356

NCTM. (2014). Principles to Actions: Ensuring Mathematical Success for All. Reston, VA.

NCTM. (2015). Calculator Use in Elementary Grades - NCTM position statement. Retrieved from https://www.nctm.org/Standards-and-Positions/NCTM-Position-Statements/

OECD. (2015). Students, Computers, and Learning. OECD Publishing. https://doi.org/10.1787/9789264239555-en

Parrot, M. A. S., \& Leong, K. E. (2018). Impact of Using Graphing Calculator in Problem Solving. International Electronic Journal of Mathematics Education, 13(3), 139-148. https://doi.org/10.12973/iejme/2704

Pierce, R., Stacey, K., \& Barkatsas, A. (2007). A scale for monitoring students' attitudes to learning mathematics with technology. Computers and Education, 48(2), 285-300. https://doi.org/10.1016/i.compedu.2005.01.006 
Retnawati, H., Wijaya, A., Yunianto, W., \& Laksmiwati, P. A. (2019). How to Enhance Students ' Participations in Mathematics Learning Using Calculator ? In Proceedings of the 24th Asian Technology Conference in Mathematics, December 15-19. Leshan, China.

Richardson, G. (2014). Calculators - challenging the rhetoric. Mathematics Teaching, (238), 6-9. Retrieved from https://www.atm.org.uk/write/MediaUploads/ Journals/MT238/Non-Member/ATM-MT238-06-08.pdf

Ronay, R., Rakes, C., Bush, S., Driskell, S., Niess, M., \& Pugalee, D. (2011). NCTM Research Brief: Using Calculators for Teaching and Learning Mathematics. Retrieved from https://www.nctm.org/uploadedFiles/Research and Advocacy/research brief and c lips/2011-Research brief 18-calculator.pdf

Ruthven, K. (2003). Creating a calculator-aware number curriculum. Canadian Journal of Science, Mathematics and Technology Education, 3(4), 437-450. https://doi.org/10.1080/14926150309556581

Savelsbergh, E. R., Prins, G. T., Rietbergen, C., Fechner, S., Vaessen, B. E., Draijer, J. M., \& Bakker, A. (2016). Effects of innovative science and mathematics teaching on student attitudes and achievement: A meta-analytic study. Educational Research Review, 19, 158-172. https://doi.org/10.1016/j.edurev.2016.07.003

Taley, I. B., \& Adusei, M. S. (2020). Junior high school mathematics teachers' knowledge in calculators. JRAMathEdu Journal of Research and Advances in Mathematics Education), 5(1), 80-93. https://doi.org/10.23917/jramathedu.v5i1.9523

Tan, C. K., Harji, M. B., \& Lau, S. H. (2011). Fostering positive attitude in probability learning using graphing calculator. Computers and Education, 57(3), 2011-2024. https://doi.org/10.1016/i.compedu.2011.05.005 


\section{APPENDIX}

\section{Mathematics and Technology Attitude Scale}

Name :

School :

Write (x) under proper response!

\begin{tabular}{|c|c|c|c|c|c|c|}
\hline & & $\begin{array}{l}\text { Hardly } \\
\text { ever }\end{array}$ & Occasionally & $\begin{array}{l}\text { About half } \\
\text { the time }\end{array}$ & Usually & $\begin{array}{l}\text { Nearly } \\
\text { Always }\end{array}$ \\
\hline 1. & $\begin{array}{l}\text { I concentrate hard in } \\
\text { mathematics }[\mathrm{BE}]\end{array}$ & & & & & \\
\hline 2. & $\begin{array}{l}\text { I try to answer } \\
\text { questions the teacher } \\
\text { asks }[\mathrm{BE}]\end{array}$ & & & & & \\
\hline 3. & $\begin{array}{l}\text { If I make mistakes, I } \\
\text { work until I have } \\
\text { corrected them [BE] }\end{array}$ & & & & & \\
\hline 4. & $\begin{array}{l}\text { If I can't do a problem, } \\
\text { I keep trying different } \\
\text { ideas }[\mathrm{BE}]\end{array}$ & & & & & \\
\hline 5. & $\begin{array}{l}\text { I have a mathematical } \\
\text { mind }[\mathrm{MC}]\end{array}$ & & & & & \\
\hline 6. & $\begin{array}{l}\text { I can get good results } \\
\text { in mathematics [MC] }\end{array}$ & & & & & \\
\hline 7. & $\begin{array}{l}\text { I know I can handle } \\
\text { difficulties in } \\
\text { mathematics [MC] }\end{array}$ & & & & & \\
\hline & & $\begin{array}{l}\text { Hardly } \\
\text { ever }\end{array}$ & Occasionally & $\begin{array}{l}\text { About half } \\
\text { the time }\end{array}$ & Usually & $\begin{array}{l}\text { Nearly } \\
\text { always }\end{array}$ \\
\hline 8. & $\begin{array}{l}\text { I am confident with } \\
\text { mathematics }[\mathrm{MC}]\end{array}$ & & & & & \\
\hline 9. & $\begin{array}{l}\text { I am interested to } \\
\text { learn new things in } \\
\text { mathematics }[\mathrm{AE}]\end{array}$ & & & & & \\
\hline 10. & $\begin{array}{l}\text { In mathematics you } \\
\text { get rewards for your } \\
\text { effort }[\mathrm{AE}]\end{array}$ & & & & & \\
\hline 11. & $\begin{array}{l}\text { Learning mathematics } \\
\text { is enjoyable }[\mathrm{AE}]\end{array}$ & & & & & \\
\hline 12. & I get a sense of & & & & & \\
\hline
\end{tabular}


satisfaction when I solve mathematics problem [AE]

13. I like using calculators for mathematics [MT]

14. Using calculators in mathematics is important [MC]

15. Mathematics is more interesting when using graphic calculators [MT]

16. I understand mathematics easier using calculators [MT] 